\title{
Leadership for development in a globalised environment ${ }^{1}$
}

\author{
S Vil-Nkomo \\ (University of Pretoria)
}

\begin{abstract}
The advancement of Africa and NEPAD depends entirely on the emergence of an African leadership for development. Issues of leadership and operational citizenship are examined and analysed. The article uses Othello to dramatize and analyse the challenges of African leadership. The scramble to save Africa from within and external is presented. The consequences of globalisation are examined. The article demonstrates that NEPAD is not a given for this continent, because certain conditions must be met which are succinctly outlined in the United Nations Millennium Declaration, the Monterrey consensus, and the United Nations Development Programme. The article raises questions of shifting goal posts.

In the final analysis, the research examines the importance of leadership if NEPAD is to succeed. Given the history of the African continent, is NEPAD a myth or a reality of development? Will future generations be able to account why NEPAD did take off or did not? Answers to these questions can be presented only if leadership for NEPAD is defined broadly and the exogenous factors are brought into the analysis.
\end{abstract}

\section{INTRODUCTION}

The previous century was dominated by major wars that affected the well being of individuals in many parts of the world. World Wars I and II had an impact on Europe in particular, but also created opportunities for rapid industrialisation and an economic boom for the United States of America. The Cold War was a conflict based on perceptions of what could happen if one of the super powers gained more control over the world. The two countries really in conflict were the United States of America (USA) and the former Union of Soviet and Socialist Republics (USSR). Unfortunately, this conflict resulted in a tremendous loss of life and destruction in countries outside the two super powers. Thus, while no actual bloody conflict ensued in the USA and the former USSR, the

\footnotetext{
1 This article was presented at the NEPAD conference on 22 April 2002, the Monterrey, Mexico International Conference on Financing for Development on 18 March 2002 to 22 March 2002; and read as guest lecture at Gonzaga University, Spokane, Washington in USA on 7-8 March 2002.
} 
developing countries had their growth and economic development negatively affected.

In particular, the Cold War, which lasted longer than any other conflict, determined the levels of development for those countries that were defined as underdeveloped and developing. Most of the countries at this level of development allied themselves with one of the two super powers on the basis that they would benefit economically. At the centre of the confusion, however, were the leaders of the different countries, who had either a narrow perspective or were driven by ideological fantasies, including the ideology of a war economy. Little of the economy of war and business seems to have been understood by some of the leaders of the underdeveloped and developing countries. Or, at the worst, even though they understood the differences, they opted or were coopted to pursue the anticipated benefits from the dependence on a war economy, mirrored on American thinking. It is common knowledge that the American economy is said to have boomed from engaging in war. It was the benefits that were derived from the First and Second World Wars that stimulated industrialisation in the United States of America.

\section{DEVELOPMENT CHALLENGES}

To underscore the development challenges confronted by leaders of most of the countries of the South, the language pursued was reminiscent of nations at war. Frantz Fanon in The Wretched of the Earth (Fanon 1963: 95) succinctly captures this dilemma:

"We have pointed out many times ... that in the underdeveloped regions the political leader is forever calling on his people to fight: to fight against colonialism, to fight against poverty and underdevelopment and to fight against sterile traditions. The vocabulary that he uses in his appeals is that of chief of staff: 'mass mobilization', 'agricultural front', 'fight against illiteracy', 'defeats we have undergone', 'victories we have won'. The young independent nation evolves during years in an atmosphere of the battlefield, for the political leader of an underdeveloped country looks fearfully at the huge distance his country will have to cover...."

The leader's intention is to mobilise its nation towards achieving development. Simultaneously they are confronted by conflict that limits their development ambition. The leaders are therefore pursuing development from a conflict paradigm. What is well researched in development studies is that the process itself has in-built contradictions.

Linked to the militarism was the assumption that development could be based on donor aid from the rich countries. Donor aid in some 
poorer nations was thought to be the kind of Marshall Plan that would assist these countries to attain their development objectives. By the middle to late 1980s, development analysts like Michael Todaro (1985: 445-446) had already observed that:

"Donor countries give aid primarily because it is in their political, strategic and/or economic self-interest to do so. While some development assistance may be motivated by moral and humanitarian desires to assist the less fortunate (e.g. emergency food relief programs), there is no historical evidence to suggest that over longer periods of time donor nations assist others without expecting some corresponding benefits (political, economic, military, etc.) in return...."

Thus, leaders who pursued development that was linked with militarism and donor aid, failed to have a positive impact on the advancement of their societies. Todaro's conclusion that "we can therefore characterize the foreign aid motivations of donor nations into two broad, but often interrelated categories: political and economic" (Ibid) opens up the debate for effective development leadership for this millennium.

In the past few years, aid was not viewed as an obstacle for development, but attempts were made to perceive it to be more friendly. These were articulated in the analyses in major world development conferences, albeit with major scepticism. The Millennium Declaration, adopted by 147 heads of state and government of 191 nations, in September 2000, sets the stage for addressing the challenges of development and the partnerships that need to be fostered between and among the critical players.

The declaration outlines the following:

- eradication of extreme poverty and hunger between 1990 and 2015;

- achievement of universal primary education by 2015 ;

- promotion of gender equality and the empowerment of women 2005;

- reduction of child mortality between 1990 and 2015;

- improvement of maternal health between 1990 and 2015;

- halting the spread of HIV/AIDS, malaria and other diseases by 2015;

- ensuring environmental sustainability with target dates of 2015 and 2020; and

- advancing a global partnership for development.

If the above were addressed systematically and implemented, a new form of leadership would have emerged when deadlines were to be reached. 


\section{CHALLENGES OF LEADERSHIP}

Continuation of some conflicts of the Cold War is still apparent. In Southern Africa, until the death of Jonas Savimbi and the initiation of peace talks, the Angolan War continued with major losses of life and the destruction of the well being of the Angolan society. In different parts of the World, the institutionalisation of ideological hatred and battles persist even after the Cold War has been declared "gone and forgotten".

The critical challenges that confront most middle developing countries, like South Africa, is how to create a development oriented leadership. This kind of leadership will place its society ahead of ideological fanaticism, and focus on the formation of alliances, aimed at addressing the development needs of their societies. However, the notion of strong development alliances seems to be most illusive to many leaders, especially because of the scramble for resources like technology and investments. The notion of the zero-sum-game still dominates the utilisation of scarce economic resources. Within their own regions, leaders tend to believe in the rhetoric they create without testing it on other levels of the societies they purport to represent. Hence, a major gap develops between themselves and their societies.

The legacy of underdevelopment and the Cold War has created an environment where African leadership styles have, in many instances, been moulded by survivalism and dependence one of the super powers or other entity. Under these circumstances, leadership is reduced to the following:

- the art of rhetoric and persuasion;

- leadership with a short term orientation aimed at winning votes every five years;

- leadership for self aggrandizement;

- leadership for individual and kinship wealth accumulation;

- leadership based on nepotism, cronyism and nannyism;

- leadership for embezzlement; and

- leadership for absolute and uncontested power.

The above characteristics do not form the basis of leadership for development. The fundamental requirement for this kind of leadership is human development and advancement. The United Nations Development Report of 1996 helps to succinctly capture this notion, which urgently demands implementation. The four essential components of human development are:

- productivity (economic growth, employment);

- equity (excess and equal opportunity for citizens); 
- sustainability (human, physical, environment); and

- empowerment (development determined and driven by the citizens for themselves and the nation).

This kind of development embraces all the critical sectors of any given society and challenges, resulting in that society clearly defining its development strategies and outcomes.

\section{FORMS OF LEADERSHIP}

Societies must begin to try and understand the different forms of leadership that exist. Some forms of leadership tend to institutionalise themselves, and as a result disempower citizens of the country. These forms of leadership also take advantage of the illiteracy rate of their societies, disregard the possibility of the existence of operational citizenship and reduce citizens to mere followers and voting instruments. If these forms of leadership persist, the new millennium will be a continuation of the previous century for most societies. Issues of societal development will remain an illusion for most citizens.

Before the notion of leadership for development is understood, the concept of operational citizenship will never exist for most of these countries. Prof Robert Warren of the University of Delaware coined the concept of operational citizenship. With this concept he tries to contextualise the role of citizens in a policy process and the country's political economy. Prof Warren is concerned that citizens must have a voice and continuously make a contribution to the development process. He fears the danger of ascribing the responsibility for the country's development only to those who have been elected into office and their operatives. As societies are built by individuals, communities, innovators and entrepreneurs, it is important to make democracy a reality in the development policy processes. The concept of operational citizenship implies that societies, which achieve it, have accomplished a modern form of leadership, which is a prerequisite for the new millennium. In addition, demagoguery in these societies have no place and citizens view themselves as having a hold and control over their development processes.

\section{DEVELOPMENT OF LEADERSHIP AND ITS PHILO- SOPHICAL GROUNDING}

As the concept of leadership for development is explored, it must be grounded in sound methodological and philosophical analysis. Thus, pursuing leadership, or having individuals perceive themselves to be 
leaders, without a paradigm grounding their output and strategies, could be short lived and unsustainable.

Leadership for development needs to be grounded in a methodology which leads to the outputs and outcomes of development being sustainable, and able to withstand the scrutiny of scientific inquiry and analysis. From a development perspective, outcomes must be distinguished from outputs, " a distinction akin to the difference between a constructed edifice and the building blocks that form its foundation" (UNDP, 2001). In this regard, the pursuit of knowledge, truth as well as outputs and outcomes, become the fundamental of leadership for development.

Leadership for development, based on the drive for epistemology, should, in the final analysis, bring about usable scientific research that contributes to the betterment of society as a whole. This is particularly essential given the extent to which knowledge drives economic growth and development. As Thurow (1996: 68) states:

"Today knowledge and skills now stand alone as the only source of comparative advantage. They have become the key ingredients in the late twentieth century's location of economic activity. In the era ahead countries have to make the investments in knowledge and skills that will create a set of man-made brainpower."

One can thus deduce that leadership for development must understand the development of human resources, as well as the collective use of knowledge to advance scarce human capital in order to advance their countries.

An added feature of leadership for development is a commitment to a participatory and people centred form of governance. To achieve this, leadership for development must be based on the following components identified by Conner (1998: vii):

- People feel in control when they can get what they want or are prepared for what they are going to get.

- Feeling in control creates a sense of dynamic balance, which is a kind of restless composure that helps people remain poised during uncertainty.

- When this balance is disrupted by unexpected events, people feel uneasy about ambiguity that is created.

- In response to this discomfort, people engage their adaptation reflex the process used to adjust to what has happened. 
- If adaptation is successful, reliable expectations can be established, and the environment, once again, becomes predictable.

- Being in a predictable environment, creates the feeling of having control over one's destiny.

What emerges, is that leadership for development is dependent on the participation of individuals and society. When citizens doubt and eventually reject their political economy, those in the leadership are immediately confronted with conflict. Political economies that create stability, development, sustainable access to opportunities, and operational citizenship, are the cornerstones for leadership for development.

\section{THE CRISES OF AFRICAN LEADERSHIP}

The dawn of independence from colonial rule in most African countries was viewed as a new beginning. Post-colonial leaders were inspired to bring about a better life for all. Most of them had good intentions, but, at the same time, paid little attention to the structural features, which were entrenched. Those who attempted to address these structural features would then be confronted with yet others that had evolved during the post-colonial period. Ben Okri, in his characterisation of Othello, draws out or identifies features in his character and circumstances that mirror the dilemma of post-colonial African leadership. As he states, due to the circumstances that he finds himself in (Okri, 1997: 76):

"Othello can't really be honest to himself. He couldn't haven risen that high and in such fearful isolation if he were. Unlike Iago, he accepts too much. He even wholly accepts the blind logic of the world in which he has sacrificed his history for ambition ... Trapped in ambition, marked by his colour, refusing to confront his predicament, he is the authentic self-betrayer. His is the white man's myth of the black man. But he is also a negative myth for black people in the West. Sign posts along roads that can lead to hell also have their own peculiar value."

African leaders, in their pursuit for harmony with more powerful nations, have often displayed the naivety and type of impotence Ben Okri's sees in his analysis of Othello. Okri gives insight into our understanding of Africa's leadership crisis, a trap that the current leadership, which aims to achieve the objectives of NEPAD, should not find itself in. Okri (1997: 77) further dramatises this leadership dilemma as follows:

"It must be admitted that there is something unbelievably simple about Othello. He comfortably personifies jealousy, and his 
particular manifestation of it is taken as a quality of his otherness. But there he is, a man of royal birth, taken as a slave, and he has no bitterness. He doesn't possess an ounce of anger, or even a sense of injustice. It is difficult to believe that he has got so far as a warrior, climbed so high in office, and yet possesses no cunning and no ability to penetrate appearances. The most irritating thing of all is his nobility, which in his predicament, is a sort of naivety. When a black man is portrayed as a noble in the West it usually means that he is neutralised. When white people speak so highly of a black man's nobility they are usually referring to his impotence."

Though Africa is today perceived as a basket case, in terms of its development stage, this continent in its totality has a lot to offer to itself and the world. Okri's analysis is thus relevant, and makes it more imperative to create leadership for development. The notion of leadership for development is premised on the strong understanding that the African continent in its global equality and competitive state is not poor. Despite this, what the continent has reaped is impoverishment and marginalisation.

\section{GLOBALIZATION AND LEADERSHIP FOR DEVELOP- MENT}

This research has contextualised leadership for development in a philosophical and scientific manner. The starting point for any application is its scientific and intellectual grounding. The logic that drives this understanding is that life is driven by discovery, modification, search for the truth, and final outcomes.

Globalisation in this millennium has emerged as a reality and a challenge all societies must confront. According to the 2002 World Bank Policy Report (2002:1): "Societies and economies around the world are becoming more integrated. Integration is the result of reduced costs of transport, low trade barriers, faster communication of ideas, rising capital flows and intensifying pressure for migration."

Globalisation does have consequences for the world. These can be summarised as follows (World Bank Report, 2002: 1-3):

- It may generally reduce poverty because of the integration of economies

- Low-income countries may break into global markets

- Rural and poor citizens may be exposed to information and job opportunities

- It will produce winners and losers both between countries and within 
- It has implications for power relations between nations, regionally and within countries

- Has an impact on cultural changes and possible destruction and

- Has ramifications for the environment, both positive and negative.

For the African continent, globalisation may lead to opportunities or tremendous failures. According to Klaus Schwab, President of the World Economic Forum in Southern Africa (World Economic Forum Report 2001:16):

“... globalization should not be seen purely in an economic context. Globalization itself needs to be globalized. Non-economic dimensions including social and environmental concerns, the prevention of conflict, and education and health must be added to the equation. Southern Africa should work towards becoming a strong hub in the globalization network."

Such thinking and analysis is corroborated and further developed by the strong emerging African leadership. This is evidenced in the New Partnership for Africa's Development (NEPAD). This evolving plan of action presents a major challenge to Africans to advance themselves, while at the same time engaging in globalisation. African leaders advance the following views (NEPAD 2001: 1):

"The case for the role of national authorities and the private institutions in guiding the globalisation agenda along a sustainable path and, therefore, one in which its benefits are more equally spread, remains strong. Experience shows that, despite the unparalleled opportunities that globalisation has offered to some previously poor countries, there is nothing inherent in the process that automatically reduces poverty and inequality."

This requires African leaders and institutions to interrogate globalisation if development is to be achieved in a significant number of African countries. It also opens up opportunities for researchers to develop NEPAD as a vehicle for Africa's development and strategically integrate the continent in the emerging new world system driven by economic competitiveness.

\section{NEPAD AND THE NEW SCRAMBLE FOR AFRICA}

The African continent continues to possess some of the most critical resources of the world. These range from mineral to natural resources. 
Though globalisation is understood to be associated with modern technologies that have reduced the slowness of communication and the conducting of international business, the African continent maintains its comparative advantage by possessing critical resources required for the advancement and development of modern world societies. In this configuration, NEPAD opens up a new scramble for Africa. The scramble for this continent is both internal and external.

\subsection{The internal scramble to save Africa}

This scramble to save Africa is driven by the desire to extricate different countries from their economic and poor governing conditions. The singular most debilitating condition of most African countries is underdevelopment. The end result out of this condition is unprecedented poverty and the persistence of killer diseases. This is the point of departure for the internal continental scramble for Africa, especially after the emergence of an economically strong and democratic South Africa.

The competitors in the scramble are South Africa, Nigeria and Senegal. South Africa possesses the most advanced economic system on the continent. Only one percent of this country's total budget is donor aid. Its infrastructure is, in some cases, more developed than that of some European countries. This country, through its business sector, continues to penetrate a number of African countries. South Africa's educational institutions of higher learning are in high demand. It is for this one reason that South Africa exports a significant number of skilled human resources to Australia, New Zealand, United Kingdom, United States of America and the Middle East. These are some of the features that place South Africa in a leading position, thus influencing the development of the African continent.

Nigeria emerges as a critical country because of several reasons. This nation maintains its position as a strong nation through its longstanding history of independence and oil and gas resources. This nation has held a strong military presence in some countries in West Africa. Nigeria has distinguished itself by having a remarkable intellectual and business human resource base. This nation has lost some of its important brainpower to the world.

Senegal represents a strong force in Francophone Africa economically, culturally and politically. This nation has played a critical role in the definition of NEPAD and its possible implementation.

In the final analysis, most African countries will emerge as important players in the NEPAD process. The comparative advantages of the different countries are systematically harnessed, to the benefit of the continent. 
This positive scramble for Africa, from within, remains that of developing competitive economies, building infrastructures that are relevant for the development of the different societies. NEPAD provides this opportunity, however, driven by a leadership for development. Good governing can only take place if this pre-condition is met. Militarism will not advance this continent and donor dependence does not lead to development.

NEPAD is a notion about this continent becoming globally relevant. Entering the global arena pre-supposes the equality of players. The age old question, Can a former slave become equal to the master because emancipation was granted? still stands. Thus, does globalisation place most African countries on an equal footing with the advantaged countries? In the African continent, to what extent can most countries compete and effectively collaborate with the South African economy? These are some of the critical research questions to be pursued by African scholars and analysts if NEPAD is to advance beyond previous plans or strategies like the Lagos Plan of Action, the Millennium Document, Plan Omega, the African Renaissance and the Five-Year Development Plans. Thus, leadership for development is an imperative for Africa's advancement, for itself and the world.

\subsection{The external scramble to save Africa}

NEPAD has granted an opportunity for other international players to consider strategies to engage the development challenges confronting this critical continent. The key players are multilateral organisations, potential investors, academic institutions and consulting companies. Bilateral assistance and arrangements are also critical for NEPAD. Major conferences in different capitals of the world also discuss and analyse NEPAD.

The interpretation and understanding are being researched in other parts of the world, particularly in those countries which are expected to make significant financial and technical assistance to the development of the African continent. Professor Jeff Herbst and Dr Gregg Mills of Princeton University paraphrase their understanding of NEPAD as follows (The Sunday Independent, April 24 2002: 7):

"Nepad is modelled on America's Marshall Plan, targeting annual investment of $\$ 64$ billion (R717 billion) to achieve a growth rate of 7 percent to reverse African economic decline and arrest poverty.

It is a simple bargain with the international community: in return for increased aid, investment and debt relief and improved 
trade access, Africa will commit itself to good governance and the rule of law."

It is obvious that NEPAD is being considered by other countries beyond those found in Africa. The drive to have a stake in the development of NEPAD and its implementation is for obvious reasons. These include:

- the rising expectations to develop this initiative with largely American, European and Asian financial resources

- the anticipation that skills from the mentioned countries will be utilised to implement NEPAD and

- that African countries have to be monitored at all times especially when attempting to implement a development strategy that will use international resources.

The latter is dramatically captured by John Matisson as follows (Sunday Business Report, April 14 2002:2):

“... Western governments were expressing alarm and incredulity at what seemed to be the failure of not Zimbabwe, but also South Africa to live up to the terms of the deal contained in New Partnership for Africa's Development (Nepad), the cornerstone of Thabo Mbeki's presidency."

To further substantiate the perceived importance of engagement by particular western countries, he concludes that (Ibid):

"Nepad is based on this exchange: in return for the West opening doors to aid and trade, Africa, through "peer review", will police its own adherence to standards of good governance, the protection of human rights and the rule of law, and the progress of economic globalisation."

Far and beyond the above, NEPAD is being subjected to the conditionalities of the New Millennium, New Agenda based on the Monterrey Consensus. These conditionalities were endorsed by leaders of the developed, developing and underdeveloped countries in Monterrey, Mexico. The essence of the consensus is:

- The mobilisation of domestic financial resources for development. This suggests the use of domestic savings that will involve public and private sector financial resources. 
- The mobilisation of international resources for development. In this case, foreign direct investment and international financial stability are viewed as being critical for international development initiatives.

- International trade is viewed as a catalyst for development. To achieve this objective, open international markets are central. Equitable multilateral trading systems must exist and trade liberalisation is of importance.

- Improving and increasing international financial and technical cooperation is relevant for development.

- The harmonisation and consistency of the international monetary, financial and trading systems would advance development.

The Monterrey Consensus is backed by strong measures to evaluate development. The agenda for this is based on the following key elements as researched and identified by the United Nations Development Programme, Evaluation Office (2001:5-6):

- The introduction of results-based management;

- The acceptance that appropriate development knowledge is found largely in the developing countries;

- Balancing performance with need;

- Organisational performance must link with individual agency performance grounded in development; and

- There must be a balance between partnerships and accountability.

The above are key indicators of the interest of the international players to influence and monitor development for Africa, that invariable includes NEPAD.

\section{SHIFTING GOAL POSTS FOR NEPAD}

Development is a complex task, where systems and structures have either collapsed or deteriorated. As the elements and objectives identified in the previous section are achieved, other unintended challenges will emerge. This can result in shifting the goal post by largely those nations that are providing the financial resources. For example, is it sufficient that democratic processes have been followed, or is it equally important which leaders have been elected in that democratic process? Furthermore, do African leaders meet the international requirements by devising their own well thought out strategies to systematically and incrementally resolve conflict? When individual African countries identify what they perceive as a fundamental requirement for economic development are they fulfilling international expectations or probably also the wisdom that is always an under-current to global utilisation of 
scarce resources? These are critical issues for further research, and will continue to confront African leadership and NEPAD.

\section{CONCLUSION}

Leadership for development of the African continent suggests an indepth understanding of what this continent wants to achieve for itself in, for example, economics, development, business, health, science. NEPAD is thus a catalyst for articulating this self definition and self interest for the African continent.

\section{Consulted literature}

Conner, D R 1998. Leading at the edge of chaos: How to create a nimble organization. New York: John Wiley \& Sons.

Fanon, F 1963. The wretched of the earth. New York: Grove Press.

Herbst, J \& Mills G 2002. Sunday Independent, April 24, 2002:15.

Matison, J 2002. Sunday Business Report. April 2002.

NEPAD 2001. The new partnership for Africa's development. Abuja: Nigeria, October 2001.

Okri, B 1977. Way of being free. London: Phoenix House.

Schwab, K 2001. World economic forum report. London: World link Publications.

Thurow, L 1966. The future of capitalism: How today's economic forces shape tomorrow's world. New York: William Morrow \& Company.

Todaro, M 1985. Economic development in the third world. London: Longman.

UNDP 1996. United Nations development report of 1996. New York. UNDP.

-, 1998. Overcoming human poverty. New York. UNDP.

-, 2001. Development effectiveness: Review of evaluative evidence. New York: UNDP.

-, 2002. Financing for development. A critical global collaborator. New York: UNDP.

-, 2002. New Millennium, New Agenda Choices. Supplement by the UNDP.

Whaites, A (ed) 2002. Masters of their own development PRSP's and the prospects for the poor. California: World vision international.

World Bank 2002. World Bank policy report 2002. Washington: World Bank. 